\title{
TEKNOLOGI PENGENDALIAN GULMA ALANG-ALANG DENGAN TANAMAN LEGUM UNTUK PERTANIAN TANAMAN PANGAN
}

\section{TECHNOLOGY OF CONTROLLING ALANG-ALANG WEED BY LEGUMES FOR AGRICULTURAL FOOD CROPS}

\author{
Ishak Juarsah \\ Balai Penelitian Tanah, JI. Tentara Pelajar No. 12, Cimanggu Bogor \\ Korespondensi : juarsah@yahoo.com
}

Diterima 2 Nopember 2014 /Disetujui 13 Mei 2015

\begin{abstract}
ABSTRAK
Di Indonesia, Alang-alang (Imperata cylindrica L. Beauv) merupakan salah satu gulma terpenting dan termasuk sepuluh gulma bermasalah di dunia. Melalui biji dan rimpang, alangalang dapat tumbuh dan menyebar luas pada hampir semua kondisi lahan. Teknologi pengendalian alang-alang telah banyak dikenal namun belum dapat menjamin eradikasi populasi alang-alang secara berkelanjutan tanpa diikuti oleh kultur teknis dan pola budidaya tanaman pangan sepanjang tahun. Hasil penelitian menunjukan bahwa lahan alang-alang dapat dikendalikan/dikelola menjadi lahan produktif setelah direhabilitasi dengan tanaman legume (Mucuna sp.) untuk usaha tani tanaman pangan lahan kering berorientasi konservasi tanah. Bahan hijauan tanaman Mucuna dapat meningkatkan kadar C-organik, memperbaiki sifat fisika, kimia tanah dan meningkatkan produksi tanaman pangan.

Kata kunci: Pengendalian alang-alang, Pertanian berkelanjutan, Tanaman legume
\end{abstract}

\begin{abstract}
In Indonesia, Alang-alang (Imperata cylindrica L. Beauv) is one of important weeds and included to ten most problematic weeds around the world. Through its seeds and roots, alangalang can grow and expand in nearly all soil conditions. Many technologies for controlling have been known but can not ensure the eradication of weeds population, however the controlling via food crops cropping systems for the whole years is the best method so far to have sustainability of the agriculture land. Research showed that alang-alang area could be controlled/managed became more productive land after rehabilitation with legume (ie Mucuna sp.) especially for dry land conservation oriented. Mucuna green materials might increase C-organic content, both soil chemical and physical improvement, furthermore increased foodcrops production.
\end{abstract}

Key words : Agriculture sustainability, Alang-alang control, Legume 


\section{PENDAHULUAN}

Tanah adalah suatu anugerah Tuhan Yang Maha Kuasa, yang perlu dipelihara dan dijaga kelestariannya agar dampak negatif terhadap pemanfaatannya dapat ditekan sekecil mungkin. Ekosistem hutan yang akan diubah menjadi lahan petanian khususnya tanaman pangan, selain dapat menurunkan fungsi hutan sebagai pengatur tata air juga akan menimbulkan degradasi lahan apabila dalam pengelolaan sejak pembukaan lahan sampai budidaya tanaman kurang memperhatikan azas kelestarian. Akibatnya produktivitas lahan terus merosot. Potensi sumberdaya alam yang terbatas sering merupakan kendala dalam proses pembangunan. Proses kerusakan sumberdaya alam dan lingkungan terutama terjadi pada daerah yang mengalami penambahan penduduk yang cepat dan penyebarannya secara tata ruang tidak seimbang terhadap jumlah dan penyebaran sumber daya alam serta daya dukung lingkungan yang ada.

Potensi sumberdaya alam yang terbatas sering merupakan kendala dalam proses pembangunan pertanian. Proses kerusakan sumberdaya alam dan lingkungan hidup terutama terjadi pada daerah yang mengalami penambahan penduduk yang cepat dan penyebarannya secara tata ruang tidak seimbang terhadap jumlah dan penyebaran sumber daya alam setempat, serta daya dukung lingkungan hidup yang ada. Selain itu, jangkauan teknologi tersebut akan dapat dimanfaatkan lebih optimal bila dukungan infrastruktur dan masalah sosial ekonomi juga dapat diatasi. Lemahnya infrastruktur dan kelembagaan menyebabkan usaha perbaikan lahan alangalang menjadi lebih komplek. Masalah yang dihadapi pada lahan alang-alang saat ini adalah bagaimana cara membuka dan mengelolanya sehingga dapat menjadi lahan pertanian yang produktif secara berkesinambungan/ berkelanjutan dan berwawasan lingkungan.

Sistim ladang berpindah merupakan salah satu sumber terjadinya kerusakan tanah karena hutan ditebang, dibiarkan mengering, kemudian dibakar dan ditanami tanaman semusim terutama padi gogo. Pada tahun pertama tingkat kesuburan tanah masih tinggi karena proses pengkayaan hara oleh pembakaran. Setelah dua atau tiga musim tanam, produksi tanaman menurun dengan tajam seiring dengan menurunnya tingkat kesuburan tanah dan meningkatnya pertumbuhan gulma terutama alang-alang sehingga petani terpaksa pindah dan kembali membuka lahan baru.

Di Indonesia diperkirakan terdapat 16 juta hektar lahan alang-alang (Imperata cylindrika L. Beauv) dan setiap tahun bertambah $150.000-200.000$ ha, terutama tersebar di Sumatera, Kalimantan, Sulawesi dan Papua pada lahan dengan kemiringan kurang dari 15\% (Supardi, 1980). Saat ini diperkirakan terdapat 9,08 juta ha lahan yang tidak produktif yang pada umumnya merupakan lahan kering yang ditumbuhi alang-alang dan semak belukar, yang dikenal dengan lahan tidur (Dirjentan, 1982). Penambahan lahan alang-alang merupakan akibat dari pengelolaan sistem usahatani yang tidak tepat yang berawal dari aktivitas manusia seperti perladangan berpindah, penebangan hutan secara liar dan sebagainya.

Dipandang dari segi pelestarian lingkungan serta penghematan dana dalam perluasan areal pertanian, maka seyogyanya lahan tersebut dimanfaatkan dengan memperbaiki produktivitasnya 
daripada membuka hutan yang dapat mengakibatkan kerusakan kualitas lingkungan (Adiningsih, 1992). Masalah yang dihadapi pada lahan alang-alang adalah bagaimana cara membuka dan cara mengelolanya sehingga menjadi lahan pertanian yang produktif secara berkesinambungan, tanpa merusak lingkungan. Hasil penelitian menunjukan bahwa lahan alang-alang dapat dikelola menjadi lahan produktif untuk usahatani tanaman pangan berkelanjutan.

Petani mengendalikan alang-alang secara manual, aman dan tidak mencemari lingkungan tetapi tidak tuntas, sehingga menghabiskan waktu 168 hari orang kerja untuk membabat, membakar dan mencangkul. Cara mekanik (bajak ternak dan mesin) dapat juga dianjurkan namun sebelumnya menghendaki pembabatan serta menghendaki lahan luas dan relatif datar. Berdasarkan beberapa hasil penelitian, teknologi alternatif yang dipakai adalah sekali alang-alang terkendali harus diikuti oleh pola budidaya tanaman pangan yang tepat sesuai dengan tipe tanah, iklim dan kebutuhan petani atas wilayah. Namun demikian harus diikuti oleh penanaman tanaman legume (cover crop) dalam upaya mempercepat peningkatan produktivitas lahan berkelanjutan.

\section{Potensi lahan kering di Indonesia}

Indonesia memiliki daratan seluas 188,2 juta ha, yang terdiri atas 148 juta ha lahan kering dan 40,2 juta ha lahan basah (Puslitbangtanak, 2001). Lahan kering yang sesuai untuk budidaya pertanian hanya sekitar 76,2 juta ha, sebagian besar terdapat di dataran rendah (70,7 juta ha), dan sisanya di dataran tinggi. Di wilayah dataran rendah, lahan yang datarbergelombang (lereng <15\%) tergolong sesuai untuk pertanian tanaman pangan, dan luasnya sekitar 23,3 juta ha. Pada lereng antara $15-30 \%$, lahan kering tersebut lebih baik diarahkan untuk tanaman tahunan (47,5 juta ha), agar bahaya erosi dapat dihindari. Di dataran tinggi yang elevasinya $>700 \mathrm{~m}$, lahan yang sesuai untuk tanaman pangan hanya sekitar 2,1 juta ha, sedangkan yang lainnya sesuai untuk tanaman tahunan dengan luas sekitar 5,5 juta ha.

Sebagian besar lahan kering (77\%) berlereng $>3 \%$ dengan topografi datar, agak berombak, bergelombang, berbukit sampai bergunung. Sedangkan lahan datar (lereng $<3 \%$ ), sekitar 42,6 juta ha (Subagyo et al., 2000), kurang dari seperempat wilayah Indonesia. Secara umum, Iahan berlereng ( $>3 \%$ ) di setiap pulau di Indonesia lebih luas dari lahan datar $(<3 \%)$. Di Pulau Jawa lahan berlereng mencapai 10,8 juta ha, sedangkan lahan datar hanya 2,4 juta ha. Di Pulau Sumatera, Iahan berlereng mencapai 33,7 juta ha, lahan datar 13,5 juta ha. Padahal kedua pulau tersebut memiliki iklim basah, dengan hujan $>2000 \mathrm{~mm} /$ tahun, sehingga bahaya erosi tergolong besar, dan telah menyebabkan degradasi lahan yang cukup berat dan menyebar luas, faktor lain yang berpengaruh juga adalah rendahnya kesuburan tanah, sehingga produktivitas lahan relatif rendah. Permasalahan dalam pengelolaan lahan kering sangat bervariasi dari satu wilayah ke wilayah lainnya, baik permasalahan teknis maupun sosialekonomis. Permasalahan tersebut antara lain: (a) miskin kadar hara dan bahan organik, (b) tingkat $\mathrm{pH}$ rendah, (c) lahan berlereng, sehingga rentan proses erosi, (d) kekurangan air, dan (e) lahan garapan sempit, kurang dari 0,5 ha/keluarga. 
Mengenal tanaman Legum (Mucuna sp.) untuk usahatani yang berkelanjutan

Tanaman Mucuna sp. merupakan jenis tanaman legum merambat yang dapat tumbuh cepat. Sehingga tanaman ini dapat digunakan untuk menekan pertumbuhan kembali alang-alang dan erosi, juga untuk menambah hara nitrogen melalui fiksasi $\mathrm{N}$ udara, serta sebagai pupuk organik yang dapat merubah P-anorganik menjadi Porganik yang lebih tersedia bagi tanaman. Adanya serasah tanaman Mucuna sp. yang telah melapuk mengakibatkan tanah tersebut menjadi lebih baik dan gembur, sehingga pengolahan tanah untuk penanaman berikutnya lebih baik diolah secara minimum daripada diolah biasa (Purnomo et al, 1989 dan Suwardjo et al, 1987).

Tanaman Mucuna sp. berfungsi sebagai tanaman rehabilitasi dan konservasi pada saat dimanfaatkan sebagai tanaman penutup tanah. Tanaman penutup tanah adalah tanaman pada lahan kering yang dapat tumbuh menutupi seluruh permukaan tanah yang berguna untuk mengendalikan erosidan memperbaiki sifat fisik tanah. Tanaman penutup tanah dibedakan menjadi empat (Agus et al., 1999), yaitu: (1) tanaman penutup tanah rendah seperti centrosema (Centrosema pubescens), pueraria (Pueraria javanica) dan benguk (Mucuna sp.); (2) tanaman penutup tanah sedang seperti lamtoro (Leucaena leucocephala) dan gamal (Gliricidia sepium); (3) tanaman penutup tanah tinggi seperti sengon (Periserianthes falcataria); dan (4) belukar lokal.

Tujuan penanaman penutup tanah adalah: (1) melindungi permukaan tanah dari erosi percikan (splash erosion) akibat jatuhnya tetesan air hujan; (2) meningkatkan kandungan bahan organik tanah dan memperbaiki sifat-sifat fisik dan kimia tanah; (3) menekan pertumbuhan gulma sehingga dapat mengurangi biaya perawatan tanaman, dan (4) meminimumkan perubahan iklim mikro dan suhu tanah, sehingga dapat menyediakan lingkungan hidup yang lebih baik bagi tanaman. Tanaman penutup tanah harus memenuhi persyaratan, antara lain : mudah diperbanyak terutama dengan biji, tumbuh cepat dan menghasilkan banyak daun, toleran terhadap pemangkasan dan injakan, bukan tanaman inang hama penyakit, sistim perakarannya tidak berkompetisi berat dengan tanaman pokok, dan mampu menekan gulma alang-alang.

Kemampuan tanaman Mucuna sp., dalam menekan pertumbuhan alang-alang dan memperbaiki kesuburan tanah ditentukan oleh kecepatan tumbuh, kandungan hara dan produksi biomasnya. Penanaman Mucuna sp. yang disertai dengan pemupukan fosfat ternyata dapat meningkatkan produksi biomasnya sekitar 2 kali lebih tinggi dari pada tanpa diberi pupuk $P$, disamping itu pemupukan $P$ juga meningkatkan kandungan hara tanaman Mucuna sp. seperti N, P, K, Ca dan C-organik (Tabel 1).

Tabel 1. Data kandungan hara daun dan batang Mucuna sp. (benguk) sebagai tanaman legum

\begin{tabular}{lcc}
\hline \multirow{2}{*}{ Kandungan } & \multicolumn{2}{c}{ Mucuna sp. } \\
\cline { 2 - 3 } & Daun & Batang \\
\hline Kadarair (\%) & 7,52 & 6,24 \\
N (\%) & 3,42 & 1,03 \\
P (\%) & 0,24 & 0,07 \\
K (\%) & 1,05 & 1,13 \\
C-organik & 45,44 & 49,88 \\
C/N organik & 13 & 48 \\
\hline
\end{tabular}

Sumber : Juarsah etal., 2001

Oleh karena itu, untuk menunjang peningkatan produktivitas tanah tanam berikutnya hasil biomassa tanaman Mucuna sp. dalam tahap rehabilitasi digunakan sebagai pupuk organik yang dibenamkan saat pengolahan tanah. Sebagai pupuk organik, Mucuna sp. mengandung unsur hara antara lain N, P, K yang beturut-turut rata-rata sebesar 2,32\%, 0,20\% dan 1,97\%. $\mathrm{Hal}$ ini berarti setiap ton biomassa kering Mucuna sp. mengandung $23,2 \mathrm{~kg} \mathrm{~N}, 20 \mathrm{~kg} P$ 
dan $19,7 \mathrm{~kg} \mathrm{~K}$ atau setara dengan $51,6 \mathrm{~kg}$ urea, $10 \mathrm{~kg}$ TSP dan 39,4 KCL. Dengan demikian, pemanfaatan Mucuna sp. sebagai pupuk organik dapat memberikan sumbangan hara bagi tanaman pangan untuk usahatani yang berkelanjutan. Irianto et a.l (1993) dan Sudharto et al. (1993) mengemukakan bahwa tanaman mucuna dapat menggemburkan tanah, meningkatkan produktivitas tanah, meningkatkan hasil tanaman, dan menekan pertumbuhan alang-alang. Menurut Sudharto et al. (1993), cara pengelolaan lahan alang-alang terbaik adalah dengan membabat alangalang, membongkar, diikuti penanaman Mucuna sp. dengan jarak $30 \mathrm{~cm} \times 20 \mathrm{~cm}$. Erfandi et al. (2001) mengemukakan bahwa tanaman Mucuna sp. selama 3 bulan dapat meningkatkan pori aerasi, pori air tersedia, indeks stabilitas agregat dan menurunkan kepadatan tanah pada tanah Ultisol di Jambi. Tala'ohu et a.l (2001) melaporkan bahwa tanaman Mucuna sp. dapat menggemburkan tanah, memelihara kelembaban tanah, mempertahankan kadar bahan organik, dan mengembalikan sebagian unsur hara ke dalam tanah. Rehabilitasi lahan alang-alang dengan tanaman Mucuna sp. pada perladangan berpindah dan pengelolaan untuk pertanian berkelanjutan pada lahan alang-alang diharapkan dapat menekan meluasnya perkembangan kedua jenis penggunaan lahan tersebut.

\section{PEMBAHASAN}

\section{A. Pengendalian Gulma Alang-Alang secara Vegetatif}

1. Tanaman Mucuna sp. penghasil bahan organik

Tanaman Mucuna sp. dapat tumbuh baik pada berbagai kondisi tanah, dari tanahtanah bereaksi masam serta kejenuhan $\mathrm{Al}$ tinggi, seperti Oxisols, Ultisols (Podsolik), sampai pada tanah yang memiliki $\mathrm{pH}$ tinggi seperti Alfisols (Mediteran) dan Vertisols (Grumusol). Hairiah (1992) mendapatkan bahwa pada tanah lapisan bawah (subsoil) setelah lapisan topsoil dihilangkan, tanaman Mucuna sp. masih mampu membentuk perakaran yang banyak, dimana biasanya hampir tidak ada perakaran yang dapat tumbuh pada lapisan bawah tersebut apabila lapisan atas masih ada.

Sumbangan tanaman Mucuna sp. terhadap kandungan unsur hara adalah melalui daun yang jatuh ke tanah atau penggunaan pupuk organik, baik berupa mulsa atau dibenam bersamaan dengan pengolahan tanah. Selain itu, mulsa berfungsi untuk memperkecil fluktuasi suhu tanah, memelihara/memperbaiki struktur tanah, mengurangi laju aliran permukaan dan erosi, meningkatkan hasil tanaman serta dapat menekan pertumbuhan gulma.

Produksi hijauan Mucuna sp. yang diberikan sebagai mulsa dapat menyumbang biomas kering rata-rata 2,8 $\mathrm{t} / \mathrm{ha} /$ musim tanam. Produksi biomassa basah dan kandungan hara Mucuna sp. dengan perlakuan tanpa pemberian $\mathrm{P}$ dan pemberian $\mathrm{P}$, kapur, dan pupuk Alam disajikan pada Tabel 2.

Penanaman Mucuna sp. Yang disertai pemberian fosfat alam memberikan dampak positif terhadap peningkatan produktivitas tanah dan ternyata mampu meningkatkan produksi biomassanya dua kali lebih tinggi dibandingkan dengan tanpa pemberian pupuk $P$ (Adiningsih dan Mulyadi, 1992). Maksud pemupukan P-alam atau TSP adalah untuk menambah ketersediaan hara $\mathrm{P}$ yang sering menjadi hara pembatas utama dan untuk mempercepat pertumbuhan tanaman Mucuna sp.

\section{Sistim usahatani terpadu dengan pola tanam menggunakan tanaman Mucuna sp.}

Walaupun pengendalian dan pengelolaan lahan alang-alang dengan cara manual dianggap mahal, namun produktivitas tanahnya bisa dipertahankan, dan terhindar dari bahaya pencemaran lingkungan akibat penggunaan herbisida yang berlebihan. Apalagi akhir-akhir ini 
banyak herbisida yang dipalsukan, sehingga akan menambah kerugian bagi petani. Dengan demikian pengelolaan lahan alangalang harus mempertimbangkan: (1) kelestarian sumberdaya tanah dan lingkungan dengan cara menghindarkan sistim pembakaran dan melakukan usaha konservasi, (2) sosial ekonomi petani, dan (3) pendapatan petani peladang.

Tabel 2. Produksi biomassa basah dan kandungan hara Mucuna sp.

\begin{tabular}{lcccccc}
\hline \multicolumn{1}{c}{ Perlakuan } & $\begin{array}{c}\text { Hasil Biomassa } \\
\text { (ton/ha) }\end{array}$ & $\mathrm{N}$ & $\mathrm{P}$ & $\mathrm{K}$ & $\mathrm{Ca}$ & $\mathrm{Mg}$ \\
\hline Tanpa P & 6,8 & 2,16 & 0,12 & 1,82 & 0,76 & 0,18 \\
TSP + Kapur & 14,9 & 2,26 & 0,21 & 2,20 & 0,80 & 0,20 \\
P.Alam North Caroline & 12,14 & 2,65 & 0,25 & 1,74 & 0,80 & 0,28 \\
P.Alam Maroko & 13,6 & 2,35 & 0,21 & 2,13 & 0,84 & 0,21 \\
Dengan P & 11,9 & 2,32 & 0,20 & 1,97 & 0,80 & 0,22 \\
\hline
\end{tabular}

Sumber data: Sri Adiningsih etal., 1993

Berdasarkan hasil penelitian Pusat Penelitian Tanah dan Agroklimat, cara pengendalian lahan alang-alang secara vegetatif menggunakan tanaman Mucuna sp. dapat menutup permukaan tanah dengan cepat, sehingga dapat menekan pertumbuhan alang-alang. Manfaat lain dari tanaman Mucuna sp. adalah menghasilkan bahan hijauan cukup tinggi sebagai bahan organik, (2) dapat meningkatkan produktivitas tanah, (3) meningkatkan hasil tanaman pangan dan, (4) bijinya dapat digunakan sebagai bahan baku tempe.

Perbandingan produksi bahan hijauan Mucuna sp. dan alang-alang akan menentukan kemampuan tanaman tersebut bersaing dengan tanaman lainnya. Berat dan persen bahan hijaun Mucuna sp. pada umumnya lebih tinggi dibanding dengan alang-alang. Hal ini menunjukan bahwa tanaman Mucuna sp. mampu bersaing dengan alang-alang.

Kemampuan tanaman Mucuna sp. untuk menekan pertumbuhan alang-alang tergantung dari sistim pengelolaan lahan alang-alang. Sistim pengeloaan lahan alangalang biasanya dengan cara alang-alang dibabat dan dibongkar akarnya kemudian ditanami Mucuna sp. dengan jarak tanam $20 \times 30 \mathrm{~cm}$. Hal ini dianggap cara yang baik karena dapat menekan pertumbuhan alangalang lebih cepat dan menghasilkan bahan hijauan lebih tinggi (Tabel 3).

\section{Sistim usahatani terpadu dengan pola tanam dengan sistem budidaya lorong}

Seperti di lahan petani lainnya, pendapatan petani di lahan alang-alang tidak bisa ditingkatkan hanya dengan usahatani tanaman pangan saja. Untuk itu komponen usahatani lainnya seperti tanaman tahunan dan ternak perlu dimasukan. Pencapaian sistim produksi tanaman pangan dalam sistim usahatani berkelanjutan juga ditentukan oleh empat faktor utama, yaitu kebijakan pemerintah, tersedianya teknologimaju, faktor e ksternal termasuk peningkatan nilai tambah dan pemasarannya serta partisipasi petani yang kesemuanya merupakan faktor yang tidak terpisahkan satu sama lainnya (Manwan, 1989). Keberhasilan pengelolaan lahan alang-alang akan mampu berfungsi ganda, yaitu dalam optimalisasi pemanfaatan sumberdaya alam, peningkatan pendapatan petani, kelestarian lingkungan, dan pengembangan wilayah.

Permasalahan pada lahan alang-alang lebih kompleks, karena sangat lemahnya daya dukung lahan dan infrastruktur. Disamping itu, kelayakan dan peranan infrastruktur dalam mendorong proses alih teknologi, belum banyak diidentifikasi secara pasti. Sebaliknya keberadaan Iahan alang-alang di Indonesia semakin mengkhawatirkan dan makin meluas dimasa mendatang. Oleh sebab itu, kajian teknologi terhadap aspek pengembangan 
penelitian perlu dilihat lebih rinci, agar usahatani pada lahan alang-alang dapat didorong lebih produktif dan optimal.

Tabel 2. Perbandingan bahan hijauan Mucuna sp. dan alang-alang pada berbagai perlakuan

\begin{tabular}{|c|c|c|c|c|}
\hline \multirow{3}{*}{ Perlakuan } & \multicolumn{4}{|c|}{ Bahan hijauan } \\
\hline & \multicolumn{2}{|c|}{ Mucuna sp. } & \multicolumn{2}{|c|}{ Alang-alang } \\
\hline & ton/ha & $\%$ & ton/ha & $\%$ \\
\hline T0 & - & - & 20 & 100 \\
\hline T1 & 15,63 & 83,93 & 3,00 & 16,07 \\
\hline $\mathrm{T} 2$ & 12,57 & 75,00 & 4,22 & 25,00 \\
\hline T3 & 11,00 & 63,09 & 6,44 & 36,91 \\
\hline T4 & 11,64 & 82,64 & 2,45 & 17,54 \\
\hline T5 & 10,68 & 76,46 & 3,29 & 23,54 \\
\hline T6 & 10,00 & 70,64 & 4,16 & 29,36 \\
\hline
\end{tabular}

Sumber data: Sudharto, et al., 1992

Keterangan :

T0 = Tanpa Mucuna sp.

T1 = Alang-alang dibabat dibongkar akarnya, ditanami Mucuna sp. Jarak tanam $20 \times 30 \mathrm{~cm}$

T2 = Alang-alang dibabat dibongkar akarnya, ditanami Mucuna sp. Jarak tanam $25 \times 50 \mathrm{~cm}$

T3 = Alang-alang dibabat dibongkar akarnya, ditanami Mucuna sp. Jarak tanam $50 \times 50 \mathrm{~cm}$

T4 = Alang-alang dibabat, ditanami Mucuna sp. Jarak tanam $20 \times 30 \mathrm{~cm}$

T5 = Alang-alang dibabat, ditanami Mucuna sp. Jarak tanam $25 \times 50 \mathrm{~cm}$

T6 = Alang-alang dibabat, ditanami Mucuna sp. Jarak tanam $50 \times 50 \mathrm{~cm}$

Hasill penelitian dengan sistim usaha tani terpadu pada lahan alang-alang yang dilaksanakan di Desa Sulit Air (DAS Singkarak), Kabupaten Solok, Propinsi Sumatera Barat pada luas areal 35 ha dengan 42 petani kooperator. Teknologi sistim usahatani yang dianjurkan/ diintroduksi adalah sistim budidaya lorong yang terdiri dari komponen tanaman pangan, tanaman buah-buahan, ternak dan pakan dengan pola sebagai berikut: (1) Sebagai tanaman pagar digunakan tanaman buah-buahan (durian, rambutan, pisang) dengan jarak tanam antar barisan dua kali jarak tanam monokultur, (2) Diantara tanaman buah-buahan ditanam tanaman pencegah erosi (Flemingia congesta), sekaligus merupakan bahan organik in-situ yang ditanam berselang-seling antar baris dengan rumput pakan ternak (King grass), dan (3) pada lahan yang relatif datar dipelihara ternak sapi dengan sistim penggemukan.

Pola tanam yang telah dikembangkan di Way Abung, Lampung, Baturaja dan Tebing Tinggi, Sumatera Selatan dapat diaplikasikan pada lahan alang-alang sebagai kelanjutan teknologi penyiapan lahan untuk usahatani tanaman pangan (Suryatna,1983; Ismail et al., 1978). Pola tersebut adalah:

1. Pola A: Jagung + padi gogo/ ubikayu/ kacang hijau.

2. Pola B: Jagung + kacang hijau I + padi gogo (ubikayu I) kacang hijau II + ubikayu II

3. Pola C: Jagung + kedelai- jagung + ubijalar- kacang tunggak

Tabel 3. Hasil tanaman pangan di lahan alang-alang, dengan sistim budidaya lorong di DAS Singkarak, Sumatera Barat

\begin{tabular}{lrrr}
\hline & \multicolumn{3}{c}{ Hasil } \\
\cline { 2 - 4 } Tanaman & Maks & Min & $\begin{array}{c}\text { Rata- } \\
\text { rata }\end{array}$ \\
\cline { 2 - 4 } & \multicolumn{3}{c}{ ton/ha } \\
\hline Kedelai & 1,52 & 0,97 & 1,10 \\
Jagung & 3,45 & 2,19 & 2,47 \\
Kacang & 0,95 & 0,65 & 0,70 \\
hijau & & & \\
\hline
\end{tabular}

Sumber: Zaini et al , 1993 


\section{B. Sifat Fisik dan Kimia Tanah setelah Ditanami Legum Mucuna sp.}

Tanaman Mucuna sp. merupakan tanaman legume cover crop yang biasa digunakan dalam pelaksanaan penelitian rehabilitasi lahan maupun aplikasi di lapangan. Tanaman Mucuna sp. selain pertumbuhannya cepat, juga menghasilkan bahan organik yang cukup banyak terutama pada bagian daun. Bahan organik merupakan sumber nitrogen tanah yang utama dan berperan cukup besar dalam proses perbaikan sifat fisik, kimia, dan biologi tanah.

Bahan organik sisa tanaman yang ditambahkan ke dalam tanah dan mengalami beberapa kali fase perombakan oleh organisme tanah untuk menjadi humus atau bahan organik tanah. Pengelolan bahan organik dari sisa tanaman secara terpadu merupakan cara pengeloaan tanah untuk meningkatkan efisiensi pupuk, produktivitas tanah dan menjamin kemantapan produksi tinggi dan berkelanjutan. Penggunaan pupuk organik ditingkat petani tanaman pangan masih sangat rendah, sementara lahan yang ditumbuhi alang-alang produktivtas lahannya rendah dan berada pada tingkat yang sangat kritis. Berdasarkan hasil para penelitian penggunaan bahan organik atau tanaman legume khususnya Mucuna,sp dapat memperbaiki tingkat kesuburan tanah sekaligus peningkatan produktivitas lahan dan tanaman serta dapat memperbaiki sifat fisik dan kimia tanah (Tabel 4 dan Tabel 5).

Tabel 4. Sifat fisik tanah setelah ditanami legum Mucuna sp.

\begin{tabular}{ccccc}
\hline \multirow{2}{*}{ Perlakuan } & \multirow{2}{*}{ B. D } & \multicolumn{2}{c}{ Ruang pori } & \multirow{2}{*}{ Air tersedia } \\
\cline { 2 - 4 } & & Total & Aerasi & \\
\cline { 2 - 4 } A $/ \mathrm{cm}^{3}$ & 1,0 & 61,5 & 29,7 & 10,7 \\
B & 1,07 & 59,6 & 25,7 & 11,4 \\
C & 1,13 & 57,4 & 17,6 & 12,7 \\
D & 1,04 & 60,8 & 26,4 & 11,5 \\
\hline
\end{tabular}

Sumber : Suwardjo et al, 1987.

Keterangan

A = Bekas Mucuna sp., sisa tanaman Mucuna sp. dikembalikan

$\mathrm{B}=$ Bekas Mucuna sp., sisa tanaman Mucuna sp. diangkut keluar

$\mathrm{C}=$ Bekas kacang tanah sebelumnya diberi kapur 2 ton/ha

$\mathrm{D}=$ Bekas rumput/bera

Tabel 5. Sifat kimia tanah setelah ditanami legum Mucuna sp.

\begin{tabular}{|c|c|c|c|c|c|c|c|c|}
\hline \multirow{4}{*}{ Perlakuan } & \multicolumn{2}{|c|}{$\mathrm{pH}$} & \multicolumn{2}{|c|}{ Bahan organik } & \multicolumn{2}{|c|}{$\mathrm{P}_{2} \mathrm{O}_{5}$ Ekstrak } & \multirow{4}{*}{$\begin{array}{c}\mathrm{K}_{2} \mathrm{O} \\
\mathrm{mg} / 100 \mathrm{~g}\end{array}$} & \multirow{4}{*}{$\begin{array}{c}\text { Al } \\
\mathrm{me} / 100 \mathrm{~g}\end{array}$} \\
\hline & \multirow{3}{*}{$\mathrm{H}_{2} \mathrm{O}$} & \multirow{3}{*}{$\mathrm{KCl}$} & $\mathrm{C}$ & $\mathrm{N}$ & $\mathrm{HCl} \% 25$ & Bray & & \\
\hline & & & \multicolumn{2}{|c|}{........\%......... } & $\mathrm{mg} / 100$ & ppm & & \\
\hline & & & & & g & & & \\
\hline A & 4,9 & 4,2 & 2,83 & 0,19 & 34 & 41,5 & 27 & 0,8 \\
\hline B & 4,2 & 3,6 & 3,11 & 0,22 & 27 & 41,4 & 9 & 2,1 \\
\hline C & 4,9 & 4,2 & 2,18 & 0,16 & 17 & 20,2 & 8 & 0,6 \\
\hline D & 4,3 & 3,7 & 2,05 & 0,16 & 16 & 19,9 & 6 & 2,0 \\
\hline
\end{tabular}

Sumber : Suwardjo et al, 1987 


\section{Produksi tanaman kedelai dan jagung pada lahan alang-alang setelah ditanami Mucuna sp.}

Bahan organik memiliki peranan penting dalam usaha peningkatan efisiensi penggunaan pupuk. Sisa tanaman yang diberikan ke dalam tanah sebagai mulsa ataupun dibenamkan dapat meningkatkan produktivitas lahan dan tanaman (Tabel 6). Dari hasil beberapa penelitian bahwa dengan memasukan tanaman legum atau Mucuna sp. Ke dalam tanah atau mulsa permanen secara terus menerus dari tahun ke tahun dapat merehabilitasi lahan, mengurangi pupuk anorganik dan pengapuran yang merupakan input tinggi.

Tabel 6. Produksi kedelai dan jagung pada lahan yang telah ditanami Mucuna sp. di Kuamang Kuning, Jambi

\begin{tabular}{|c|c|c|}
\hline \multirow{3}{*}{ Perlakuan } & \multicolumn{2}{|c|}{ Berat biji kering jemur } \\
\hline & Kedelai & Jagung \\
\hline & \multicolumn{2}{|c|}{---Kg/ha--- } \\
\hline$A$ & 1150,3 & 2251 \\
\hline B & 1259,0 & 1461 \\
\hline C & 756,3 & 1282 \\
\hline D & 561,0 & 1097 \\
\hline
\end{tabular}

Sumber : Suwardjo et al., 1987

Keterangan

$\mathrm{A}=$ Bekas Mucuna sp., sisa tanaman Mucuna sp. dikembalikan

$\mathrm{B}=$ Bekas Mucuna sp., sisa tanaman Mucuna sp. diangkut keluar

$\mathrm{C}=$ Bekas kacang tanah sebelumnya diberi kapur 2 ton/ha

$\mathrm{D}=$ Bekas rumput/bera

\section{SIMPULAN}

1. Upaya untuk mempertahankan produktivitas lahan alang - alang setelah lahan direhabilitasi hendaknya dilakukan penerapan sistem usahatani terpadu dan berkelanjutan yaitu pemupukan, pola tanam tumpangsari, penambahan bahan organik dengan pengembalian sisa panen dan sistim pertanaman lorong serta pencegahan erosi.
2. Pengendalian meluasnya gulma alangalang dapat dilakukan dengan cara vegetatif yaitu dengan usaha menanam tanaman penutup tanah dari famili Leguminosae seperti tanaman Mucuna sp., flemingia sebagai tanaman lorong, karena selain dapat menekan pertumbuhan alang-alang, dapat juga memperbaiki sifat fisik, kimia dan biologi tanah sehingga lambat laun dapat meningkatkan produktivitas lahan dan produksi tanaman berkelanjutan.

3. Salah satu alternatif dalam pengendalian gulma alang-alang dapat dilakukan dengan pendekatan sistim usahatani terpadu yang terdiri dari komponen tanaman pangan, tahunan, penghasil bahan organik (legum) dan ternak.

\section{DAFTAR PUSTAKA}

Agus, F.N. Ginting dan A. Dariah . 1996. Sumberdaya Alam Daerah Aliran Sungai Cimanuk Hulu dan teknologi konservasial. Hal 113-127 dalam Prosiding Lokakarya Pembahasan Hasil Penelitian Analisis pengelolaan Daerah Aliran Sungai. Garut, 20-24 Nopember 1995. Pusat Penelitian Tanah dan Agroklimat, Bogor.

Erfandi, D. I. Juarsah dan U.Kurnia, 2001. Pebaikan sifat fisik tanah Ultisol Jambi melalui pengelolaan bahan organik dan guludan. HIm 171-182, dalam Prosiding Seminar Nasional Reorientasi Pendayagunaan Sumberdaya Tanah, Iklim dan Pupuk; Byuku I Cipayung Bogor, 31 Oktober- 2 Nopember 2000. Puslitbangtanak, Bogor

Ismail, I.G. Basa dan S. Effendi, 1978. Cropping System research in transmigration areas South Sumatera, Dir.Gen Trans CRIA.

Irianto,G,S.H. Tala'ohu, dan H. Suwardjo, 1993. Rehabilitasi lahan Alang-alang 
akibat perladangan berpindah melalui peningkatan produktivitas lahan dan konservasi tanah, hlm 34-38 dalam Risalah Hasil Penelitian Tanah dan Agroklimat, Pusat Penelitian Tanah dan Agroklimat, Bogor.

Juarsah, I. dan Undang Kurnia. 2001. Peningkatan kualitas Iahan terdegradasi menggunakan bahan organik di propinsi Jambi. Universitas Lampung, Bandar Lampung.

Adiningsih, S. dan Mulyadi, 1993. Alternatif Teknik Rehabilitasi dan Pemanfaatan Lahan Alang-alang. Dalam Pemanfaatan Lahan Lahan Alang-alang untuk Usahatani Berkelanjutan. Prosiding Seminar Lahan Alang-alang, Bogor 1 Desember 1992, Pusat Penelitian Tanah dan Agroklimat, Bogor. Badan Litbang Pertanian.

Manwan, I. 1989. Over view of farming system reseach in Indonesia, presented at 20th ARFS working komodity group meeting Puncak, Bogor.

Makarim, A.K. S.NIngrum ,1991. Pengaruh pengapuran dan bahan organik terhadap tanaman kedelai pada tanah masam. Hal. 419-429. Dalam Prosiding Lokakarya Penelitian Komoditas dan Studi Khusus. 419-429.

Purnomo, J., Mulyadi, dan Istiqlal Amien. 1992. Pembangunan Jangka Panjang Tahap II Subsektor Tanaman Pangan. Rapat Kerja Nasional Departemen Pertanian, Jakarta 3-7 Pebruari 1992.
Soepardi, G. 1980. Alang-alang and soil fertility. BIOTROP Workshop on Alangalang BIOTROP special Publication 5:9-14

Suryatna, E. 1983. Pola tanam dan Pengembangannya di Indonesia. Lokakarya Teknologi dan Dampak Penelitian Pola Tanam, Bogor 20-21 Juni 1983.

Suwardjo, A.Barus dan M.Sodik, 1987. Pengaruh cara pembukaan dan pengelolaan lahan alang-alang terhadap erosi dan produktivitas tanah. HIm 225302 dalam Prosiding Pertemuan Teknis Penelitian Tanah, Pusat Penelitian Tanah, Bogor.

Soerjani,M. 1970. Alang-alang Imperata Cylidrica (L) Beauv (1812): pattern of growth as related to it problem of control, BIOTROP Spescial Publications 5 : 9-14

Tato Sudharto, H. Suwardjo, D. Erfandi dan T. Budhyastoro, 1992 Permasalahan dan Penanggulangan Lahan Alang-alang. Dalam Pemanfaatan Lahan Lahan Alangalang untuk Usahatani Berkelanjutan. Prosiding Seminar Lahan Alang-alang, Bogor 1 Desember 1992, Pusat Penelitian Tanah dan Agroklimat, Bogor. Badan Litbang Pertanian.

Zulkifli Zaini dan Zainal Lamid, 1992. Alternatif Teknologi Budidaya Tanaman Pangan pada Lahan Alang-alang. Dalam Pemanfaatan Lahan Alang-alang untuk Usahatani Berkelanjutan. Prosiding Seminar Lahan Alang-alang, Bogor 1 Desember 1992, Pusat Penelitian Tanah dan Agroklimat, Bogor. Badan Litbang Pertanian. 